\title{
Composition, abundance and ecology of phytoplankton communities of Loktak Lake, Manipur, India
}

\section{B.K. Sharma}

Department of Zoology, North-Eastern Hill University, Permanent campus, Umshing, Shillong, Meghalaya 793022, India Email: bksharma@nehu.ac.in

\begin{abstract}
Phytoplankton communities of Loktak Lake (a Ramsar site), studied during November 2002-October 2004, reveal the occurrence of 75 and 71 species, indicate monthly richness ranging between $47 \pm 6$ and $49 \pm 3$ species and record $50.0-83.2$ and $64.5-84.0 \%$ community similarities during two annual cycles respectively. Chlorophyta ( $33 \pm 5$ and $35 \pm 5$ species) show qualitative dominance and importance of Closterium > Cosmarium > Staurastrum > Micrasterias > Gonatozygon species. Phytoplankton (206 \pm 58 and $220 \pm 53 \mathrm{n} / \mathrm{l})$ comprise between $45.1 \pm 6.5$ and $42.9 \pm 5.8 \%$ of net plankton abundance, indicate trimodal annual patterns and record peak abundance during winter. Chlorophyta $(111 \pm 20$ and $119 \pm 15 \mathrm{n} / \mathrm{l})$, the dominant quantitative component, indicate winter peaks; Closterium > Staurastrum $>$ Gonatozygon $>$ Micrasterias species contribute significantly to their abundance. Ceratium hirudinella $(43 \pm 52$ and $39 \pm 37 \mathrm{n} / \mathrm{l})$ is the sole important individual species of phytoplankton. Dinophyta > Bacillariophyta are sub-dominant groups and Euglenophyta > Cyanophyta > Chrysophyta show very low densities. Phytoplankton communities are characterized by higher species diversity, higher evenness and lower dominance. Abiotic factors register limited influence on richness and abundance of phytoplankton and on abundance of constituent groups. Multiple regression indicates relatively lower influence of fifteen abiotic factors on richness of phytoplankton and higher cumulative influence on abundance of phytoplankton, Chlorophyta, Dinophyta and Bacillariophyta.
\end{abstract}

Keywords: Composition, Floodplain Lake, Loktak, Phytoplankton, Ramsar site, synecology

Date of publication (online): 26 August 2009 Date of publication (print): 26 August 2009 ISSN 0974-7907 (online) | 0974-7893 (print)

Editor: R. Jindal

Manuscript details:

Ms \# 02193

Received 04 May 2009

Final received 30 June 2009

Finally accepted 28 July 2009

Citation: Sharma, B.K. (2009). Composition, abundance and ecology of phytoplankton communities of Loktak Lake, Manipur, India. Journal of Threatened Taxa 1(8): 401-410.

Copyright: (C) B.K. Sharma 2009. Creative Commons Attribution 3.0 Unported License. JoTT allows unrestricted use of this article in any medium for non-profit purposes, reproduction and distribution by providing adequate credit to the authors and the source of publication.

Author Details: B.K. ShARma is a Professor in Department of Zoology and Dean, School of Life Sciences and is a specialist in the fields of limnology and acquatic biodiversity.

Acknowledgement: This study is undertaken under the "Potential for Excellence Program (Focused Area: Biosciences) of North-Eastern Hill University, Shillong. The author is thankful to the G.B. Pant Institute of Himalayan Environmental Development, Almora for a research grant during which plankton samples for this study were collected. Thanks are due to the Head, Department of Zoology, North-Eastern Hill University, Shillong for necessary laboratory facilities.

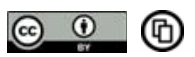

OPEN ACGESS | FREE DOWNLOAD

\section{INTRODUCTION}

The floodplain lakes cover a water spread area of about 0.12 million ha in northeastern India, are mainly located in the states of Assam and Manipur and exhibit significant fishery production potential (Sugunan 1997). Little is, however, known so far about their biological productivity in general and about composition, abundance and ecology of phytoplankton in particular. Investigations on the latter from northeastern region are confined to fewer preliminary publications from Assam (Yadava et al. 1987; Baruah \& Das 1997; Goswami \& Goswami 2001) indicating poor ecological data due to inadequate species determination. On the other hand, Sharma (2004) gave useful information on phytoplankton ecology of a floodplain lake of upper Assam while Sharma (in press) analyzed phytoplankton communities of Deepor Beel - a Ramsar site and an important floodplain lake of Assam.

This study on the composition and synecology of phytoplankton of Loktak Lake, a Ramsar site, an important floodplain lake of northeastern India and the largest freshwater wetland of India, is of ecological importance. Observations were made on monthly variations in richness, abundance of phytoplankton, their constituent groups, community similarities, species diversity, dominance and evenness for two annual cycles. Remarks are made on the influence of abiotic factors on richness and abundance of phytoplankton communities.

\section{Materials and Methods}

The present study is a part of limnological survey (undertaken during November, 2002 - October, 2003) in Loktak Lake (93 $46^{\circ}-93^{\circ} 55^{\prime} \mathrm{E} \& 24^{\circ} 25^{\prime}-24^{\circ} 42^{\prime} \mathrm{N}$; area: $286 \mathrm{~km}^{2}$; max. depth: 4.58m, mean depth: 2.07m; altitude: $768.5 \mathrm{~m}$ ) located in Bishnupur / Imphal districts of Manipur. This large natural freshwater wetland is characterized by floating mats of vegetation called as "Phumdi" which are inhabited by the Critically Endangered Brow-antlered Deer (Cervus eldi eldi). Common aquatic plants of this floodplain lake include Eichhornia crassipes, Hydrilla verticellata, Euryale ferox, Vallisnaria spiralis, Utricularia flexuosa, Trapa natans, Lemna trisula, Pistia striates, Salvinia, Nymphaea spp., Nymphoides spp., Nelumbo mucifera, Potamageton spp., Azolla pinnata, Sagittaria spp, and Cyperus spp. etc.

The present observations were undertaken at regular monthly intervals at one selected sampling site at Sendra $\left(93^{\circ} 47^{\prime} 45.61^{\prime \prime} \mathrm{E} \& 24^{\circ} 30^{\prime} 56.75^{\prime \prime} \mathrm{N}\right)$. Water samples collected monthly were analyzed for various abiotic factors following APHA (1992) while water temperature, specific conductivity, $\mathrm{pH}$ and dissolved oxygen were recorded by the field probes. Monthly qualitative and quantitative net plankton samples were collected by nylobolt plankton net (No. 25) and were preserved in 5\% formalin. The 
former were screened and phytoplankton taxa were identified following Needham \& Needham (1962), Islam \& Haroon (1980), Adoni et al. (1985) and Fitter \& Manuel (1986). Quantitative plankton samples were analyzed for abundance $(\mathrm{n} / \mathrm{l})$ of net plankton, phytoplankton and constituent groups.

Sorensen's index, Shannon's indices, Berger-Parker's index and Pileou's index were calculated following Ludwig \& Reynolds (1988) and Magurran (1988). Significance of temporal variations of biotic parameters was ascertained by ANOVA (two-way). Ecological correlations between abiotic and biotic parameters were determined by simple correlation coefficients ( $\mathrm{r}$ ). Multiple regression $\left(\mathrm{R}^{2}\right)$ was used to ascertain cumulative effect of 15 abiotic factors (water temperature, rainfall, $\mathrm{pH}$, specific conductivity, dissolved oxygen, free carbon dioxide, alkalinity, hardness, phosphate, nitrate, sulphate, silicate, chloride, dissolved organic matter and total dissolved solids) on phytoplankton and their groups.

\section{Results And Discussion}

\section{Abiotic parameters}

Water temperature indicates sub-tropical nature of Loktak Lake. Specific conductivity exhibits low ionic concentrations (Table 1) of this Ramsar site and, hence, warrants its inclusion under 'Class I' category of trophic classification vide Talling \& Talling (1965). Slightly acidic and soft waters of this floodplain lake depict moderate dissolved oxygen, low free $\mathrm{CO}_{2}$, low concentration of micro-nutrients and other abiotic factors. In general, the abiotic factors differ from Deepor Beel (Sharma in press), distinctly in the recorded ranges of $\mathrm{pH}$, alkalinity and hardness.

\section{Phytoplankton composition, richness and community similarities}

Seventy-five species of phytoplankton (Table 2), belonging to six groups, documented from Loktak exhibit their speciose and diverse nature and, hence, reflect greater environmental heterogeneity of this Ramsar site. Total richness is distinctly higher than only 33 species examined earlier in an unpublished report (Bhatia 1979) from this wetland as well as than 59 species reported from Deepor Beel (Sharma in press). The present collections are characterized by qualitative dominance of Chlorophyta (56 species) and distinct qualitative importance of species of five desmid genera (64.3\%) namely Closterium (11 spp.) > Cosmarium (7 spp.) = Staurastrum (7 spp.) > Micrasterias (6 spp.) > Gonatozygon (5 spp.). Desmid diversity is considered to be an indicator of slightly acidic, Calciumpoor waters with low ionic concentrations (Payne 1986), this interesting generalization is confirmed by the salient features of water quality of Loktak Lake. Further, higher desmid richness is concurrent with phytoplankton communities of various (sub)tropical aquatic environs of northeastern India (Sharma unpublished). The species and generic diversity of Loktak phytoplankton distinctly outnumbers the earlier records of Baruah et al. (1993), Acharjee et al. (1995), Sanjer \& Sharma (1995), Goswami \& Goswami (2001), and Sharma (2004). The general qualitative dominance of the Chlorophyta observed in this study corresponds with the results of Goswami \& Goswami (2001) and Sharma (in press) but differs from the greater diatom richness reported by Baruah et al. (1993) and Sharma (2004).
Table 1. Abiotic factors of Loktak Lake (2002-04)

\begin{tabular}{lll}
\hline Abiotic Factors & Range & Mean \pm SD \\
\hline Air temperature ${ }^{\circ} \mathrm{C}$ & $16.4-30.8$ & $23.4 \pm 4.1$ \\
Water temperature ${ }^{\circ} \mathrm{C}$ & $14.5-28.5$ & $21.4 \pm 4.0$ \\
Rainfall mm & $0-370.4$ & $112.1 \pm 116.8$ \\
$\mathrm{pH}$ & $6.01-6.74$ & $6.38 \pm 0.23$ \\
Specific Conductivity $\mu \mathrm{S} / \mathrm{cm}$ & $75.0-132.0$ & $98.9 \pm 19.7$ \\
Dissolved Oxygen mg/l & $4.6-9.0$ & $6.2 \pm 1.1$ \\
Free CO $\mathrm{mg} / \mathrm{l}$ & $6.0-13.0$ & $9.5 \pm 2.1$ \\
Alkalinity mg/l & $10.0-25.0$ & $16.0 \pm 4.4$ \\
Hardness mg/l & $24.0-54.0$ & $38.1 \pm 8.2$ \\
Phosphate mg/l & $0.12-0.32$ & $0.23 \pm 0.12$ \\
Nitrate mg/l & $0.27-0.42$ & $0.34 \pm 0.04$ \\
Sulphate mg/l & $0.54-0.99$ & $0.86 \pm 0.12$ \\
Silicate mg/l & $8.40-12.70$ & $10.4 \pm 1.2$ \\
Chloride mg/l & $10.0-20.1$ & $14.9 \pm 3.1$ \\
Dissolved organic matter mg/l & $0.91-2.1$ & $1.38 \pm 0.40$ \\
Total dissolved solids mg/l & $0.20-0.81$ & $0.46 \pm 0.22$ \\
\hline
\end{tabular}

Phytoplankton richness varies between 37-57 (47士6)

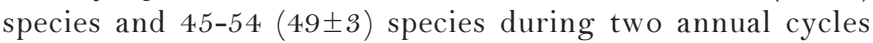
respectively (Table 2 ); it records significant monthly variations $\left(\mathrm{F}_{11,23}=4.821, \mathrm{P}<0.005\right)$ but shows insignificant annual variations. Richness shows (Fig. 1) peaks during post-monsoon (October) and higher species number during winter (December) during both years and lowest richness is noticed during January (first year) and March (second year). The present study, however, exhibits no definite pattern of periodicity of richness of any group or species of phytoplankton. This generalization concurs with the author's earlier remarks in two floodplain lakes of Assam (Sharma 2004, in press) while Loktak phytoplankton reflect higher range of richness variations. Further, the richness exhibits limited influence of individual abiotic factors and indicates significant negative correlations with nitrate $(\mathrm{r}=$ $0.458)$, sulphate $(r=-0.569)$ and silicate $(r=-0.415)$. Multiple regression also registers relatively lower cumulative influence of 15 abiotic factors on phytoplankton richness $\left(\mathrm{R}^{2}=0.579\right)$.

Phytoplankton of Loktak Lake indicate community similarities (vide Sorenson's index) ranging between 50.0$84.0 \%$ with marginal variations during two successive years of the study period i.e., 50.0-83.2 \% (Table 3 ) and 64.5-84.0 \% (Table 4) respectively. The recorded values differ from wider similarity ranges noticed by Sharma (2004, in press). The similarity, however, varies between $70-80 \%$ in majority of instances $(72 \%)$ included in the matrix during the second year while only $31.2 \%$ instances belong to the stated range and $48.5 \%$ instances indicate $60-70 \%$ similarity during the first year. Hierarchical cluster analysis shows notable differences in clusters groupings during the study period. It registers higher associations among phytoplankton communities during December-September-August-November-October and exhibits more differences in January-July-June during the first year (Fig. 2). On the other hand, higher associations are observed during January-September-December and more differences are apparent during March-July-February in the following year (Fig. 3).

Chlorophyta, the most speciose component of phytoplankton, include 56 and 51 species during two annual cycles respectively and significantly influence temporal variations of richness of the latter $(r=0.913)$. Richness of this group registers insignificant monthly and annual variations. It follows (Fig. 4) relatively wider range of variations during first year (20-40, $33 \pm 5$ species) than in the succeeding year 


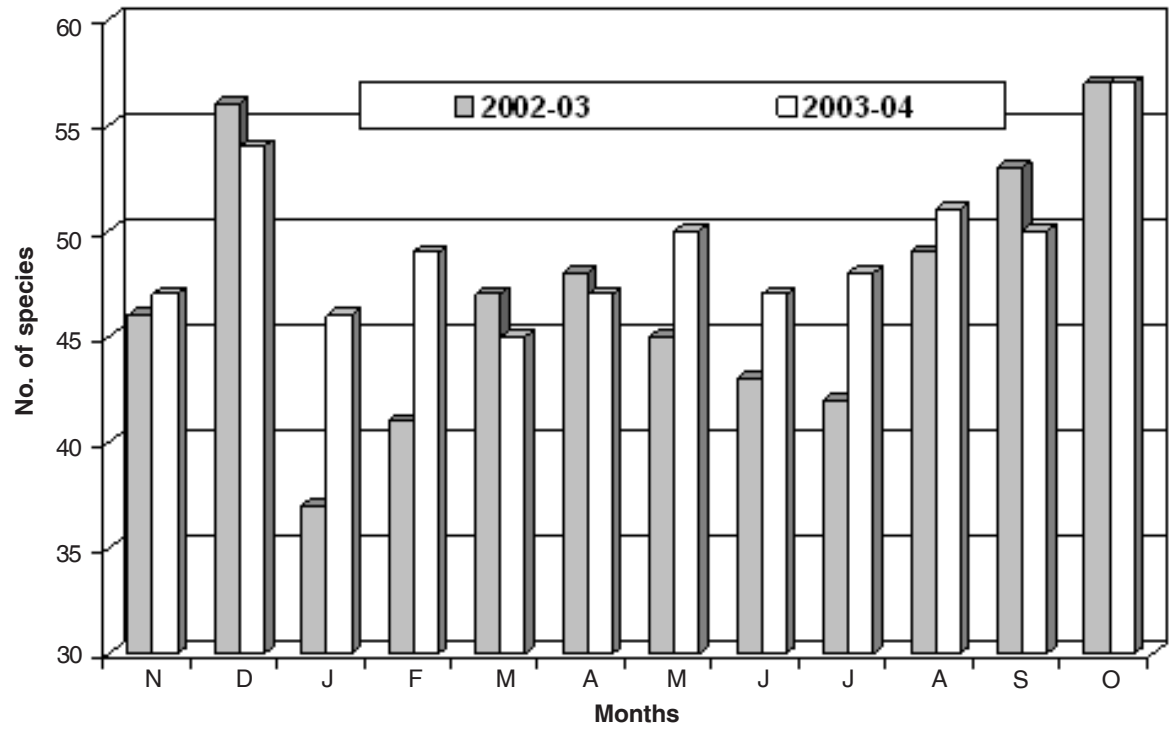

Figure 1. Monthly variations in phytoplankton richness

Table 2. Temporal variations of phytoplankton of Loktak Lake

\begin{tabular}{|c|c|c|c|}
\hline & 2002-03 & 2003-2004 & Study period \\
\hline \multicolumn{4}{|c|}{ Qualitative Chlorophyta $>$ Bacillariophyta $>$ Dinophyta $=$ Cyanophyta $=$ Euglenophyta $>$ Chrysophyta } \\
\hline Phytoplankton & 75 species & 71 species & 75 species \\
\hline$\%$ Similarity & $50.0-83.2$ & $64.5-84.0$ & $50.0-84.0$ \\
\hline \multicolumn{4}{|l|}{ Monthly Richness } \\
\hline Phytoplankton & $37-57 \quad 47 \pm 6$ & $45-54 \quad 49 \pm 3$ & $37-57 \quad 48 \pm 5$ \\
\hline Chlorophyta & $24-40 \quad 33 \pm 5$ & $30-42 \quad 35 \pm 3$ & $24-42 \quad 34 \pm 4$ \\
\hline \multicolumn{4}{|c|}{ Quantitative Chlorophyta > Dinophyta > Bacillariophyta } \\
\hline Phytoplankton n/l & $155-369 \quad 206 \pm 58$ & $158-323220 \pm 53$ & $155-369213 \pm 56$ \\
\hline$\%$ composition & $38.0-60.0 \quad 45.1 \pm 6.5$ & $34.8-54.8 \quad 42.9 \pm 5.8$ & $34.8-60.0 \quad 44.1 \pm 6.3$ \\
\hline Species Diversity & $2.520-3.805 \quad 3.283 \pm 0.354$ & $2.876-3.741 \quad 3.507 \pm 0.259$ & $2.520-3.805 \quad 3.404 \pm 0.329$ \\
\hline Dominance & $0.074-0.523 \quad 0.283 \pm 0.123$ & $0.055-0.409 \quad 0.158 \pm 0.103$ & $0.055-0.523 \quad 0.180 \pm 0.118$ \\
\hline Evenness & $0.698-0.941 \quad 0.853 \pm 0.074$ & $0.739-0.956 \quad 0.902 \pm 0.064$ & $0.698-0.956 \quad 0.879 \pm 0.075$ \\
\hline \multicolumn{4}{|c|}{ Different groups (n/l) } \\
\hline \multirow{2}{*}{$\begin{array}{l}\text { Chlorophyta n/l } \\
\% \text { composition }\end{array}$} & $78-137 \quad 111 \pm 20$ & $104-155 \quad 119 \pm 15$ & $78-155 \quad 115 \pm 18$ \\
\hline & $34.7-77.3 \quad 56.2 \pm 12.6$ & $38.1-5.8 \quad 56.5 \pm 8.3$ & $34.7-77.3 \quad 56.2 \pm 10.5$ \\
\hline \multirow{2}{*}{$\begin{array}{l}\text { Dinophyta n/l } \\
\% \text { composition }\end{array}$} & $13-193 \quad 53 \pm 48$ & $17-138 \quad 49 \pm 36$ & $13-193 \quad 51 \pm 43$ \\
\hline & $6.9-52.3 \quad 22.8 \pm 12.5$ & $10.4-49.3 \quad 20.5 \pm 0.9$ & $6.9-52.3 \quad 22.0 \pm 11.8$ \\
\hline \multirow{2}{*}{$\begin{array}{l}\text { Bacillariophyta } n / l \\
\% \text { composition }\end{array}$} & $11-44 \quad 31 \pm 10$ & $17-5538 \pm 11$ & $11-5535 \pm 11$ \\
\hline & $6.7-21.8 \quad 15.4 \pm 3.7$ & $10.5-22.4 \quad 17.3 \pm 3.0$ & $6.7-22.4 \quad 16.3 \pm 3.5$ \\
\hline \multirow{2}{*}{$\begin{array}{l}\text { Euglenophyta n/l } \\
\% \text { composition }\end{array}$} & $2-12 \quad 7 \pm 3$ & $3-13 \quad 7 \pm 3$ & $2-13 \quad 7 \pm 3$ \\
\hline & $0.5-5.9 \quad 3.4 \pm 1.7$ & $1.3-4.1 \quad 3.0 \pm 0.9$ & $0.5-5.9 \quad 3.2 \pm 1.4$ \\
\hline \multirow{2}{*}{$\begin{array}{l}\text { Cyanophyta n/l } \\
\% \text { composition }\end{array}$} & $1-7 \quad 3 \pm 2$ & $3-7 \quad 5 \pm 2$ & $1-7 \quad 4 \pm 2$ \\
\hline & $0.3-4.3 \quad 1.5 \pm 1.4$ & $0.6-5.1 \quad 2.8 \pm 1.4$ & $0.3-5.1 \quad 2.1 \pm 1.5$ \\
\hline Chrysophyta $\quad n / l$ & $0-1$ & $0-4 \quad 2 \pm 1$ & $0-4 \quad 1 \pm 1$ \\
\hline \multicolumn{4}{|l|}{ Important taxa (n/l) } \\
\hline Ceratium hirudinella & $4-193 \quad 43 \pm 52$ & $5-130 \quad 39 \pm 37$ & $4-193 \quad 41 \pm 45$ \\
\hline Closterium spp. & $8-4 \quad 21 \pm 8$ & $17-43 \quad 29 \pm 9$ & $8-43 \quad 25 \pm 9$ \\
\hline Staurastrum spp. & $5-30 \quad 17 \pm 7$ & $11-24 \quad 18 \pm 4$ & $5-30 \quad 18 \pm 6$ \\
\hline Gonatozygon spp & $6-25 \quad 13 \pm 6$ & $7-26 \quad 17 \pm 6$ & $6-26 \quad 15 \pm 6$ \\
\hline Micrasterias spp. & $1-26 \quad 10 \pm 7$ & $3-15 \quad 10 \pm 3$ & $1-26 \quad 10 \pm 6$ \\
\hline Cosmarium spp. & $2-8 \quad 5 \pm 2$ & $2-11 \quad 6 \pm 3$ & $2-11 \quad 6 \pm 2$ \\
\hline
\end{tabular}

Table 3. Phytoplankton community similarities (Sorenson's index) 2002-03

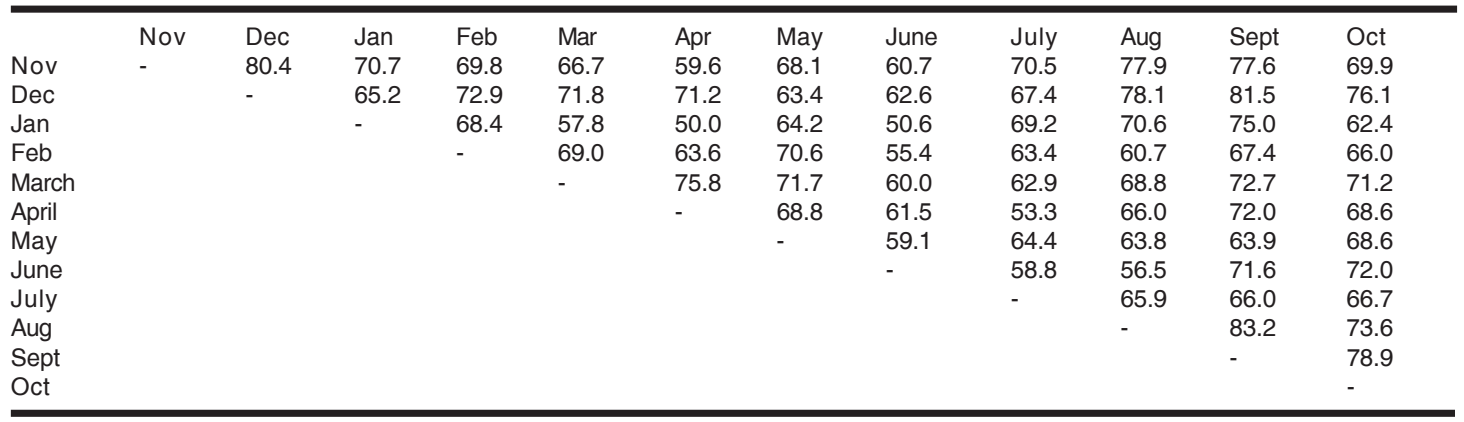


Table 4. Phytoplankton community similarities (Sorenson's index) 2003-04

\begin{tabular}{|c|c|c|c|c|c|c|c|c|c|c|c|c|}
\hline & Nov & Dec & Jan & Feb & March & April & May & June & July & Aug & Sept & Oct \\
\hline Nov & - & 76.5 & 66.0 & 69.4 & 74.5 & 72.9 & 73.5 & 73.7 & 72.2 & 74.8 & 74.2 & 78.1 \\
\hline Dec & & - & 82.0 & 73.1 & 76.0 & 78.4 & 76.9 & 75.3 & 77.7 & 74.3 & 79.6 & 73.9 \\
\hline Jan & & & - & 79.2 & 69.6 & 66.0 & 70.8 & 73.1 & 69.5 & 68.0 & 84.2 & 71.8 \\
\hline March & & & & & - & 74.5 & 72.9 & 64.5 & 75.8 & 74.2 & 69.5 & 71.8 \\
\hline April & & & & & & - & 79.6 & 71.6 & 70.1 & 72.7 & 74.2 & 76.2 \\
\hline May & & & & & & & - & 68.0 & 70.7 & 71.3 & 68.7 & 76.6 \\
\hline Aug & & & & & & & & & & - & 74.0 & 81.5 \\
\hline Sept & & & & & & & & & & & - & 75.5 \\
\hline Oct & & & & & & & & & & & & - \\
\hline
\end{tabular}

Rescaled Distance Cluster Combine

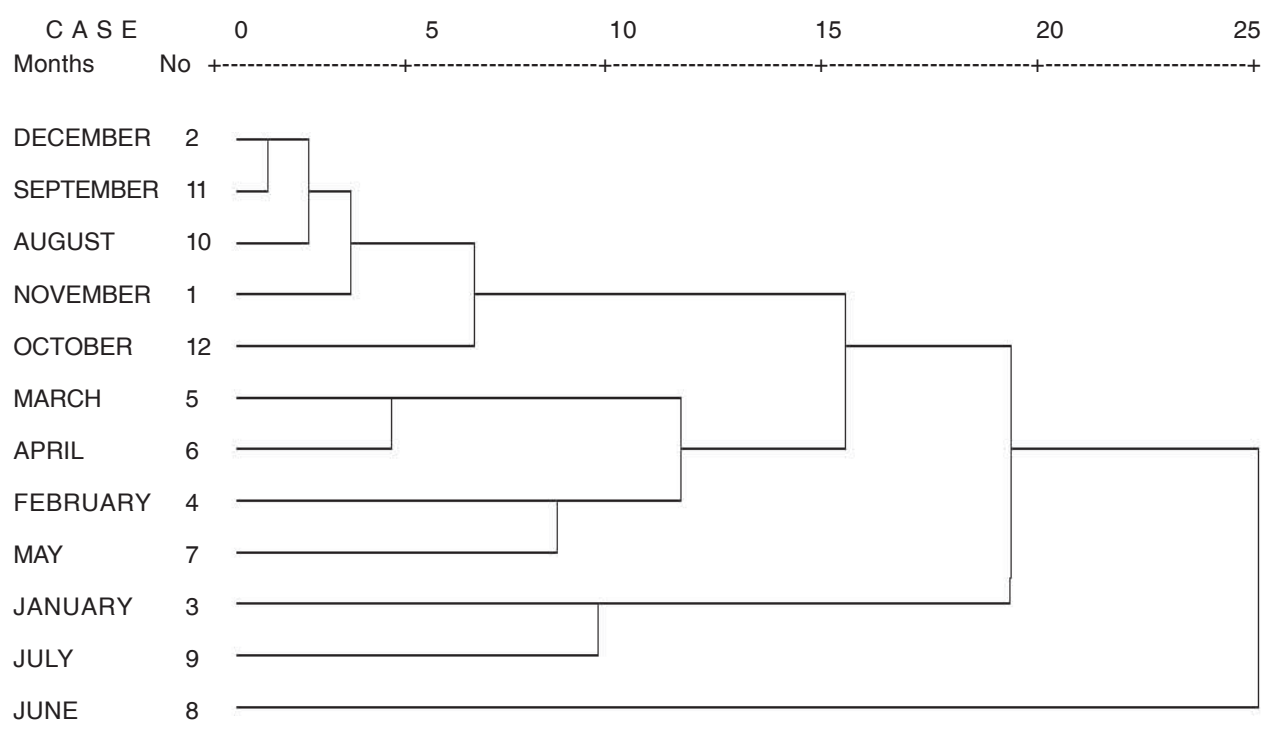

Figure 2. Dendrogram showing hierarchical cluster analysis of phytoplankton communities (2002-03)

Rescaled Distance Cluster Combine

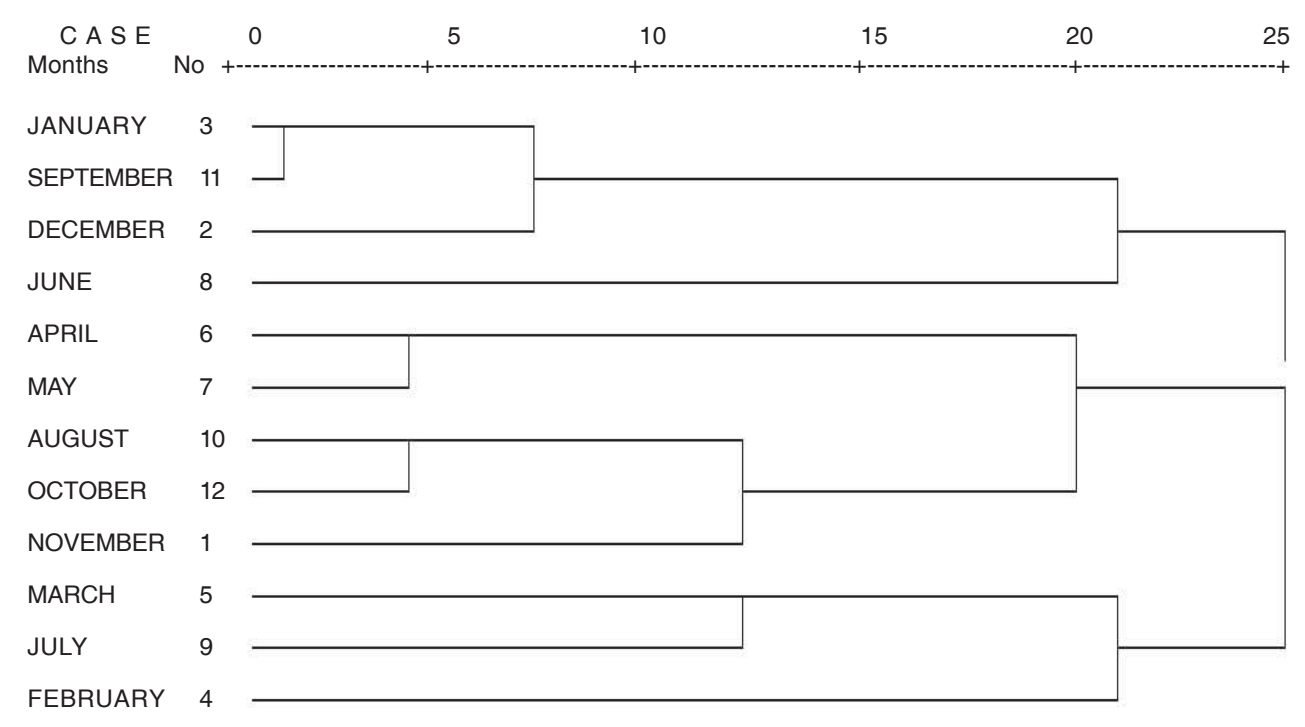

Figure 3. Dendrogram showing hierarchical cluster analysis of phytoplankton communities (2003-04) 

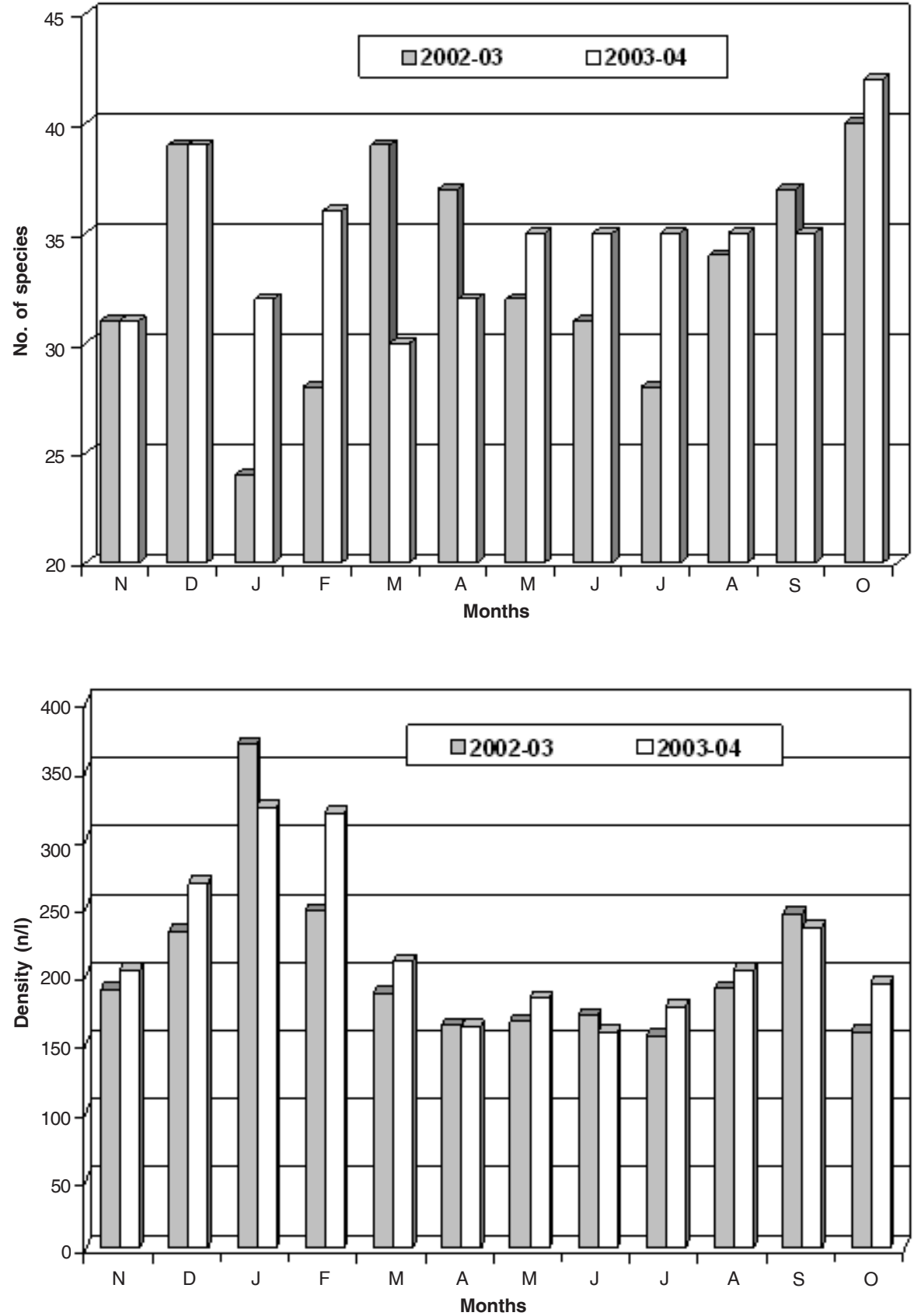

Figure 4. Monthly variations in Cholorophyta richness

Figure 5. Monthly variations in phytoplankton abundance
(30-42, $35 \pm 3$ species) and exhibits an indefinite pattern of temporal periodicity with peaks during post-monsoon (October) during both years but shows minima during January, 2002 and February, 2003. The Chlorophyta richness registers no significant correlation with any individual abiotic factor, while multiple regression registers higher commutative influence $\left(\mathrm{R}^{2}\right.$ $=0.829)$ of 15 abiotic factors.

\section{Phytoplankton abundance}

Phytoplankton form a sub-dominant quantitative component of net plankton (44.1 $\pm 6.3 \%)$, following zooplankton, throughout the study period except only during January ( $1^{\text {st }}$ year $)$ and January-February $\left(2^{\text {nd }}\right.$ year $)$. The stated trend corresponds with the results of Sharma (2004, in press) and Sharma \& Sharma (2008) while it is in contrast to phytoplankton dominance reported from the floodplain lakes from Kashmir (Kaul \& Pandit 1982), Bihar (Rai \& Dutta Munshi 1982; Baruah et al. 1993; Sinha et al. 1994; Sanjer \& Sharma 1995), West Bengal (Sugunan 1989), Assam (Yadava et al. 1987; Baruah \& Das 1997; Goswami \& Goswami 2001), Kerala (Krishnan et al. 1999) and Maharashtra (Patil 2002).

Phytoplankton abundance (Table 2) ranges between 155$369(206 \pm 58 \mathrm{n} / \mathrm{l})$ and $158-323(220 \pm 53 \mathrm{n} / \mathrm{l})$ during the two years respectively; it exhibits significant monthly $\left(\mathrm{F}_{11.23}=\right.$ 15.026, $\mathrm{P}<0.005)$ but insignificant annual variations. Abundance follows (Fig. 5) broadly identical trimodal yearly patterns with higher densities during winter season and peaks during January, maxima during post-monsoon (September), a small maxima during June and minima during July. The present results differ from multimodal patterns noticed in Deepor Beel (Sharma in press) and also from the bimodal periodicity reported by Yadava et al. (1987) and Sanjer \& 

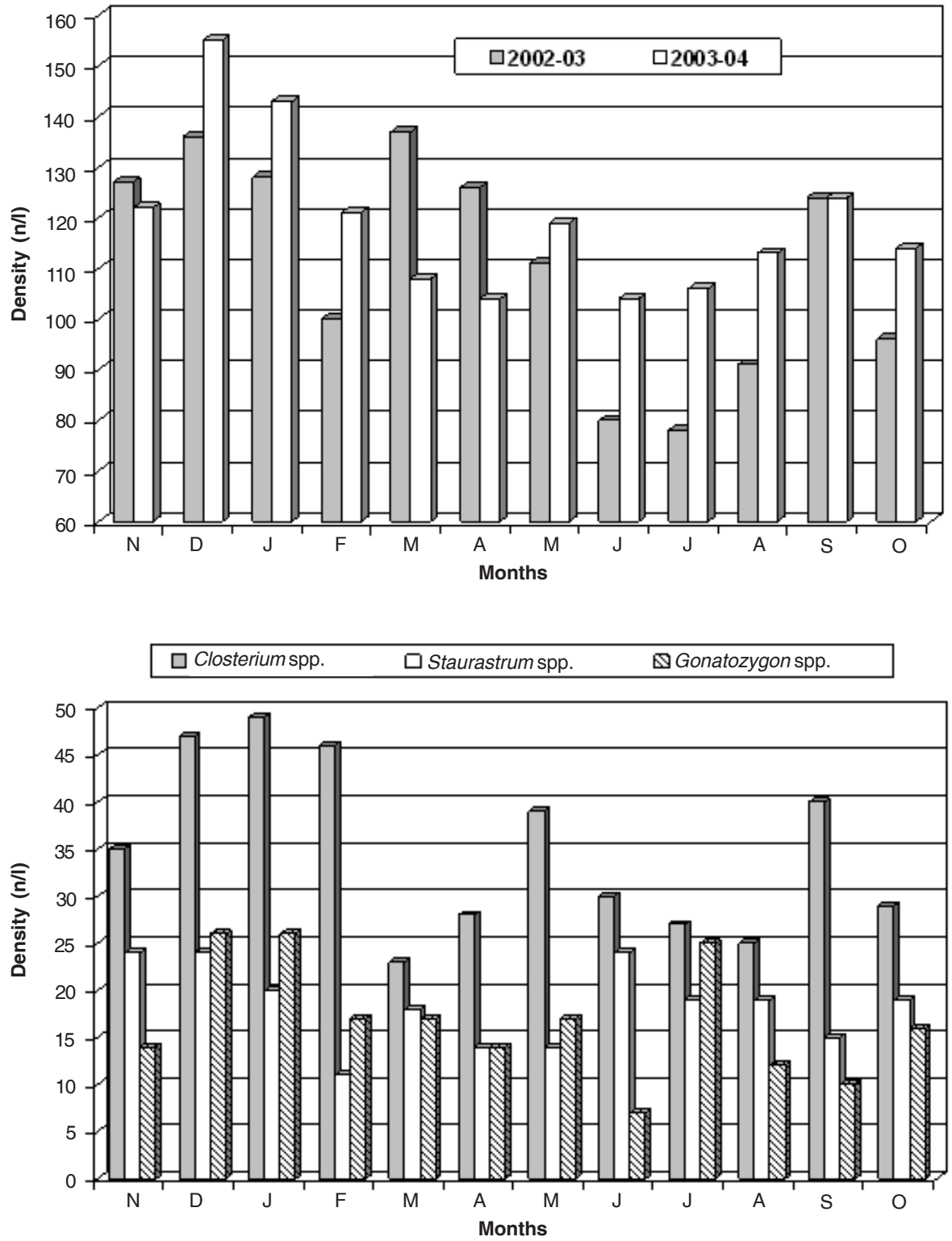

Figure 6. Monthly variations in Chlorophyta abundance
Figure 7. Monthly variations in abundance of dominant genera of Chlorophyta (2002-03)
Sharma (1995). On the other hand, the peak density noticed presently during winter concurs with the results of Yadava et al. (1987) and Sanjer \& Sharma (1995) while it differs from early summer maxima reported by Sharma (2004). Phytoplankton abundance in Loktak Lake is yet lower than that from Deepor Beel (Sharma in press), while it is marginally higher than in Samuajan Beel (Sharma 2004). In addition, the density is distinctly lower than the reports from certain beels of West Bengal (Sugunan 1989; Vass 1989) and Bihar (Baruah et al. 1993; Sanjer \& Sharma 1995); these differences are attributed to soft nature of water of Loktak with low ionic concentrations and resulting in lower general biological productivity.

Of the recorded parameters, phytoplankton abundance is inversely correlated with water temperature $(r=-0.795)$, free carbon dioxide $(r=-0.568)$, silicate $(r=-0.490)$ and total dissolved solids $\left(r_{1}=-0.465\right)$. On the contrary, fifteen abiotic factors exert significantly higher cumulative influence $\left(\mathrm{R}^{2}=\right.$ 0.952). Further, the present results record insignificant positive correlation between abundance of phytoplankton and zooplankton. This aspect is in contrast to significant positive correlations between the two communities recorded earlier by Yadava et al. (1987) and Sharma (2004, in press).

Chlorophyta, the sole dominant quantitative component, notably influence temporal variations of phytoplankton $(\mathrm{r}=$ 0.547) of Loktak Lake and, hence, concur with earlier reports of Yadava et al. (1987), Choudhary \& Singh (2001), Goswami \& Goswami (2001) and Sharma (in press). The dominance pattern, however, differs from the predominance of the diatoms over the green algae noticed by Baruah et al. (1993) and Krishnan et al. (1999) as well as from nearly equal importance of the two groups reported by Sharma (2004). Chlorophyta

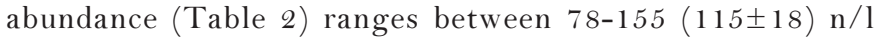
and comprises between $56.2 \pm 10.5 \%$ of phytoplankton. ANOVA registers significant monthly $\left(\mathrm{F}_{11.23}=3.084, \mathrm{P}<0\right.$. $005)$ and insignificant annual variations in their abundance. The green-algae follow (Fig. 6) trimodal but marginally different annual patterns with higher abundance during winter (December-January), peaks during December and minima during July and June respectively during two years. The 

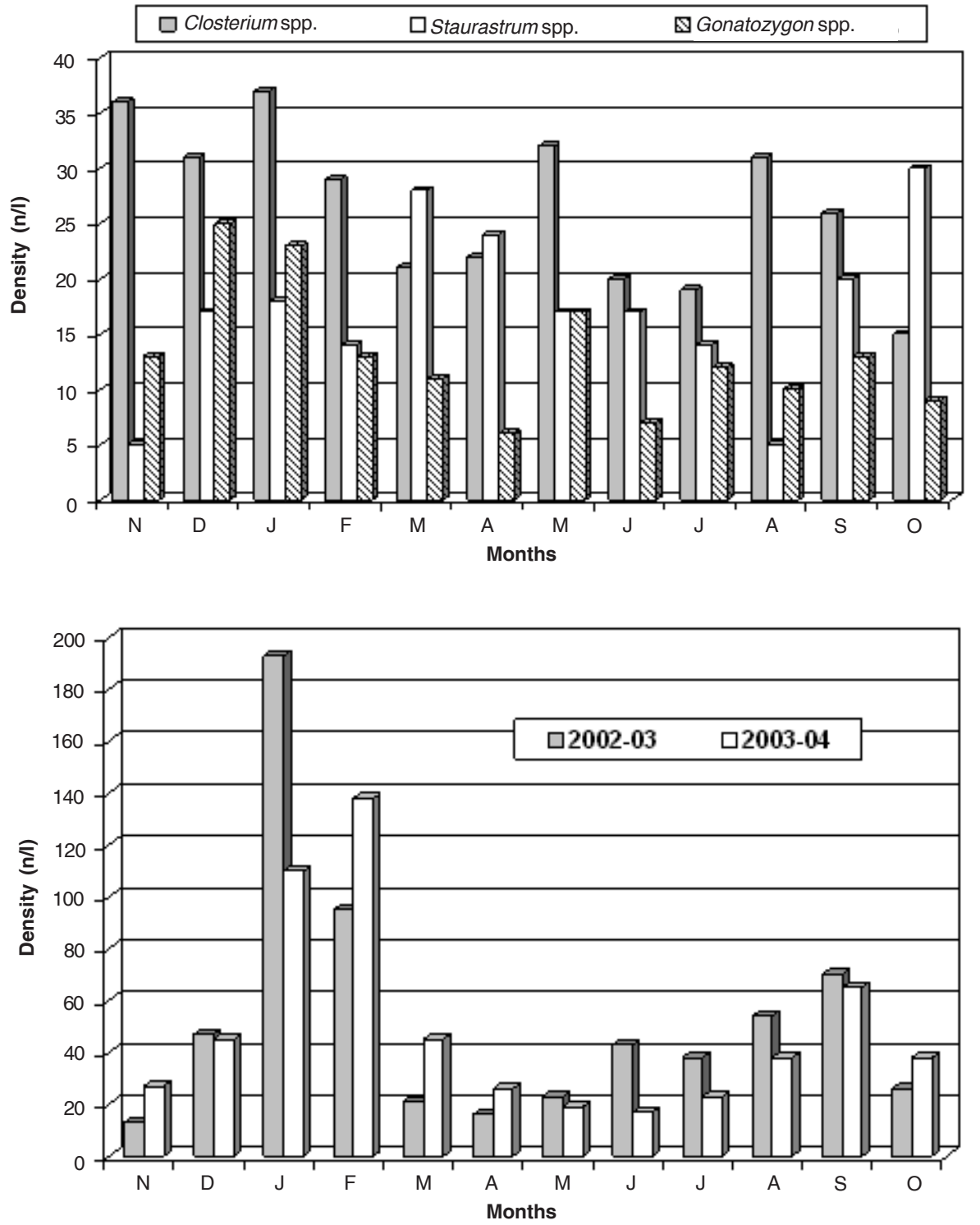

Figure 8. Monthly variations in abundance of dominant genera of Chlorophyta (2003-04)
Figure 9. Monthly variations in Dinophyta abundance present study shows notably higher abundance of this group than the earlier report from Samuajan beel (Sharma 2004), while the density broadly corresponds with the report from Deepor Beel (Sharma in press) but differs distinctly from the same in their higher percentage contributions. Amongst the recorded abiotic factors, Chlorophyta abundance is inversely correlated with water temperature $(\mathrm{r}=-0.585)$, free $\mathrm{CO}_{2}(\mathrm{r}=-$ $0.412)$, hardness $(r=-0.553)$, nitrate $(r=-0.473)$, silicate $(r=$ - 0.565), chloride $(\mathrm{r}=-0.559)$ and total dissolved solids $(\mathrm{r}=-$ 0.710 ), while multiple regression registers higher cumulative influence $\left(\mathrm{R}^{2}=0.825\right)$ of 15 abiotic factors.

Chlorophyta are characterized by quantitative importance of certain desmid taxa (Figs. 7-8) namely Closterium spp. (25 \pm 9 $\mathrm{n} / \mathrm{l})>$ Staurastrum spp. $(18 \pm 6 \mathrm{n} / \mathrm{l})>$ Gonatozygon spp. $(15 \pm 6$ $\mathrm{n} / \mathrm{l})$ while Micrasterias spp. $(10 \pm 6 \mathrm{n} / \mathrm{l})$ and Cosmarium spp. $(6 \pm 2 \mathrm{n} / \mathrm{l})$ also deserve mention. This salient feature is in contrast to lack of any such dominance pattern noticed in Samuajan (Sharma 2004) and Deepor (Sharma in press) beels of Assam. The stated taxa, however, exhibit lack of definite temporal periodicity. Of these, only Closterium spp., and Gonatozygon spp. exhibit significant annual $\left(\mathrm{F}_{1.29}=16.209, \mathrm{P}\right.$ $\left.<0.005 ; \mathrm{F}_{1.23}=7.663, \mathrm{P}<0.001\right)$ and monthly $\left(\mathrm{F}_{11.23}=4.335\right.$,
$\left.\mathrm{P}<0.01 ; \mathrm{F}_{11.23}=6.511, \mathrm{P}<0.002\right)$ variations and register negative correlations with water temperature $(r=-0.525, r=-$ 0.456).

Dinophyta (13-193, $51 \pm 43 \mathrm{n} / 1,22.0 \pm 11.8 \%)$, a subdominant quantitative component of phytoplankton of Loktak Lake, follow wider range of abundance and record only significant monthly temporal variations $\left(\mathrm{F}_{11.23}=7.068, \mathrm{P}<\right.$ 0.001). This group exhibits (Fig. 9) distinctly higher abundance (peaks) during winter (February/January) in both years and notably contributes to higher winter densities of phytoplankton during this period in particular. These interesting features are supported by their inverse correlation with water temperature $(\mathrm{r}=-0663)$. Besides, this group is inversely correlated with free $\mathrm{CO}_{2}(\mathrm{r}=-0.490)$, while 15 abiotic factors exercise higher cumulative influence $\left(\mathrm{R}^{2}=0.839\right)$ on their quantitative variations. Ceratium hirudinella (4-193, 41 \pm 45 $\mathrm{n} / \mathrm{l}$ ), the sole important individual phytoplankton species observed in Loktak Lake, exhibits broadly bimodal periodicity with distinct annual peaks during winter. This species is solely responsible for Dinophyta periodicity as well as for contributing to phytoplankton abundance during winter. ANOVA affirms significant monthly $\left(\mathrm{F}_{11.23}=7.991, \mathrm{P}<0.005\right)$ density 

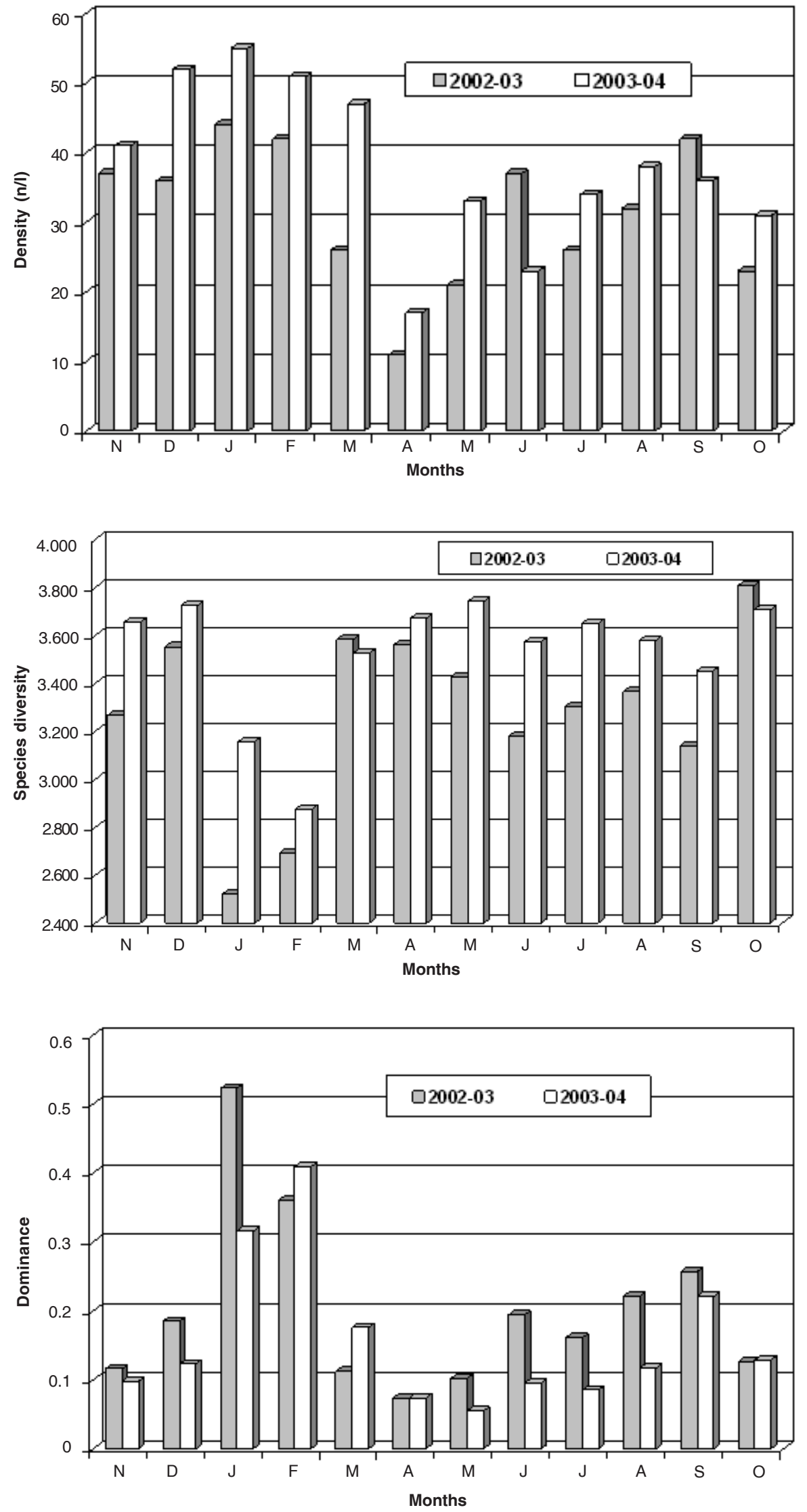

Figure 10. Monthly variations in Bacillariophyta abundance

Figure 11. Monthly variations in phytoplankton species diversity

Figure 12. Monthly variations in phytoplankton dominance 


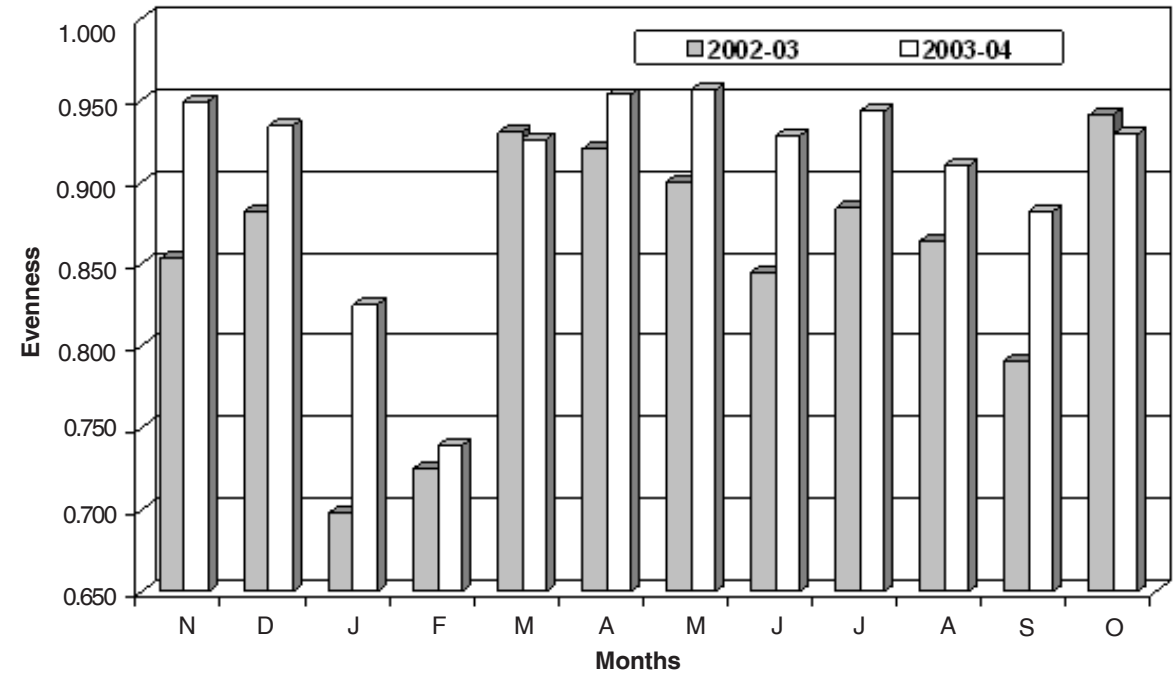

Figure 13. Monthly variations in phytoplankton evenness variations of $C$. hirudinella. The present observations broadly conform with the results in Deepor Beel (Sharma in press) relating to sub-dominant role of Dinophyta and quantitative significance of $C$. hirudinella but differ from the latter in broader range of variations and winter dominance patterns. These results are, however, in contrast to very poor abundance of this group noticed in Samuajan Beel (Sharma 2004).

Bacillariophyta $(35 \pm 11 \mathrm{n} / \mathrm{l} ; 16.3 \pm 3.5 \%)$ form another subdominant component of phytoplankton and exhibit significant annual $\left(\mathrm{F}_{1.23}=6.369, \mathrm{P}>0.02\right)$ and monthly $\left(\mathrm{F}_{11.23}=4.559, \mathrm{P}\right.$ $>0.005)$ quantitative variations. The abundance of this group is lower than earlier reports of Sharma (2004, in press). The diatoms follow (Fig. 10) multimodal and trimodal annual patters during two years respectively and record higher abundance during winter with peaks in January. The last feature is supported by their inverse correlation with water temperature $(\mathrm{r}=-0.627)$. Further, winter peaks observed in this study are in contrast to their summer peaks reported in Deepor Beel (Sharma in press). Besides, Bacillariophyta are inversely correlated with free $\mathrm{CO}_{2}(\mathrm{r}=-0.427)$ and silicate $(\mathrm{r}=-0.627)$, while multiple regression registers moderately higher influence $\left(\mathrm{R}^{2}=0.774\right)$ of 15 abiotic factors.

Euglenophyta $>$ Cyanophyta $>$ Chrysophyta indicate very low densities and contribute insignificant quantitative components of phytoplankton of Loktak Lake. These remarks are in contrast to sub-dominant role of the Cyanophyta and relatively higher abundance of the other two groups noticed in Deepor Beel (Sharma in press).

\section{Species diversity, evenness and dominance}

The present results are characterized by higher species diversity of phytoplankton (2.520-3.805, 3.404 \pm 0.329$)$; the range may be misleading as its values are higher $(<3.0)$ in major part of the study period except during winter (JanuaryFebruary). Further, it follows significant annual $\left(\mathrm{F}_{1.23}=17.084\right.$, $<0.005)$ and monthly $\left(\mathrm{F}_{11{ }_{29}}=8.861, \mathrm{P}<0.005\right)$ variations. The diversity (Fig. 11) does not follow any definite annual and monthly patterns; peak values are recorded during October (post-monsoon) and May (summer) while minima are noticed during January and February (winter) during two years respectively. Species diversity is positively correlated with richness of Phytoplankton $(r=0.645)$ and Chlorophyta $(r=$
0.633 ) and is negatively correlated with abundance of phytoplankton $(\mathrm{r}=-0.623)$, Bacillariophyta $(\mathrm{r}=-0.440)$ and Dinophyta $(r=-0.835)$. The present observations indicate higher species diversity than the reports from Dighali Beel (Acharjee et al. 1995) and Samuajan Beel (Sharma 2004) of Assam while range and mean value is also marginally higher than the report from Deepor Beel (Sharma in press). Further, indefinite annual periodicity and summer peak noticed during second year of the present study concur with the results of Deepor phytoplankton (Sharma in press).

Phytoplankton dominance shows wider range (0.055-0.523, $0.180 \pm 0.118)$ and registers significant monthly $\left(\mathrm{F}_{11.23}=9.298\right.$, $\mathrm{P}<0.005)$ and insignificant annual variations. It follows (Fig. 12) trimodal and bimodal annual patterns and shows generally low values during the study period except for peaks in January and February during two years respectively. The later, in turn, correspond with peaks of Ceratium hirudinella - the sole dominant species observed in Loktak Lake. Dominance is inversely correlated with species diversity $(r=-0.904)$, and richness of phytoplankton $(\mathrm{r}=-0.408)$ and Chlorophyta $(\mathrm{r}=-0.442)$ while it is positively correlated with abundance of phytoplankton $(\mathrm{r}$ $=0.853)$, Bacillariophyta $(\mathrm{r}=0.590)$ and Dinophyta $(\mathrm{r}=0.972)$. The salient feature of low dominance though broadly corresponds with earlier reports of Sharma (2004, in press) but differs from the same in the broad range observed presently.

Phytoplankton communities of Loktak Lake exhibit higher evenness (0.698-0.956, 0.879 \pm 0.075$)$ which, in turn, reflects equitable abundance of various species; this statement holds valid during major part of the study period except particularly during winter (January and February). Evenness follows (Fig. 13) trimodal and multimodal annual with peaks during October and November and minima during January and February during two years respectively; the last feature again corresponds with peaks of Ceratium hirudinella. Evenness is positively correlated with species diversity $(r=0.975)$, and richness of Phytoplankton $(r=0.460)$ and Chlorophyta $(r=0.473)$. It is, however, inversely correlated dominance $(r=-0.934)$, and abundance of Phytoplankton $(\mathrm{r}=-0.730)$, Bacillariophyta $(\mathrm{r}=$ -0.494) and Dinophyta $(r=-0.862)$. In general, higher evenness and lower dominance broadly concur with earlier results of Sharma (2004, in press) in two floodplain lakes of Assam as well as with phytoplankton communities of certain other 
aquatic environments of northeastern India (Sharma 1995; Sharma \& Lyngdoh 2003; Sharma \& Lyngskor 2003).

To sum up, diverse and speciose phytoplankton communities of Loktak Lake are characterized by distinct qualitative importance of Chlorophyta and the desmids. Phytoplankton and their individual groups reflect lack of definite periodicity of richness. Chlorophyta show quantitative dominance; Dinophyta > Bacillariophyta are sub-dominant groups; Ceratium hirudinella is the only quantitatively notable species while Closterium, Cosmarium, Staurastrum, Micrasterias, Gonatozygon species show importance. Phytoplankton communities are characterized by higher diversity, lower dominance and higher evenness. Individual abiotic factors depict little or limited influence on richness and abundance but register higher cumulative influence. The present study limited to one sampling station, though provides useful information on phytoplankton ecology of Loktak, may not reflect full environmental heterogeneity of this interesting Ramsar site. Future investigations on phytoplankton in different parts (pats) of Loktak basin with special focus on periphyton associations with diverse aquatic macrophytes are desired and have been initiated.

\section{RefERENCES}

Acharjee, B., A. Dutta, M. Choudhury \& V. Pathak (1995). Phytoplankton species diversity indices in Dighali beel, Assam, India. Environment \& Ecology 13: 660 -662.

Adoni, A.D., G. Ghosh, S.K. Chourasia, A.K. Vaishya, M. Yadav \& H.G. Verma (1985). Workbook on Limnology. Pratibha Publishers. 216 pp.

APHA (1992). Standard Methods for the Examination of Water and Wastewater (1 $8^{\text {th }}$ ed.). American Public Health Association, Washington D.C., 1198 pp.

Baruah, A., A.K. Sinha \& U.P. Sharma (1993). Plankton variability of a tropical wetland, Kawar (Begusarai), Bihar. Journal of Freshwater Biology 5: 27-32.

Baruah, B.K. \& M. Das (1997). Effect of paper mill effluent on plankton population of wetland. Environment \& Ecology 15: 770-777.

Bhatia, B. (1979). Ecology of Loktak Lake. Final Technical Report, Department of Science and Technology, Government of India, New Delhi.

Choudhary, S. \& D.K. Singh (2001). Phytoplankton population of Boosra lake (Gaighat block, Muzaffarpur, Bihar). Environment \& Ecology 19: 171-174

Fritter, R. \& R. Manuel (1986). Field guide to the Freshwater life of Britain and North-West Europe. William Collins Sons \& Co. Ltd, London.

Goswami, M.M. \& N. Goswami (2001). Studies on productivity indicators in Mori beel of Assam. Tropical Zoology 2 \& 3: 1-9.

Islam, A.K.M.N. \& A.K.Y. Haroon (1980). Desmids of Bangladesh. Internationale Revue gesammten Hydrobiologie 65(4): 551-604.

Kaul, V. \& A.K. Pandit (1982). Biotic factors and food chain structure in some typical wetlands of Kashmir. Pollution Research 1: 49-54.

Krishnan, K.H., S. Thomas, S. George, R.P. Murugan, S. Mundayoor \& M.R. Das (1999). A study on the distribution and ecology of phytoplankton in the Kuttanad wetland ecosystem, Kerala. Pollution Research 18: 261-269.

Ludwig, J.A. \& J.F. Reynolds (1988). Statistical Ecology: A Primer on Methods and Computing. John Wiley \& Sons, New York, 337pp.

Magurran, A.E. (1988). Ecological Diversity and its Measurement. Croom Helm Limited, London, 179pp.

Needham, J.G. \& P.R. Needham (1962). A Guide to the Study of Freshwater Biology. Holden-Day, Inc., San Francisco, 108pp.

Payne, A.R. (1986). The ecology of Tropical lakes and rivers. John Wiley \& Sons, New York, $301 \mathrm{pp}$.

Rai, D.N. \& J.M. Dutta-Munshi (1982). Ecological characteristics of 'Chaurs' of North Bihar, pp. 89-95. In: Gopal, B., R.E. Turner, R.G. Wetzel \& D.F. Winghon (eds.). Wetlands-Ecology and Management, Vol.
II. International Scientific Publications and National Institute of Ecology, Jaipur, India.

Sanjer, L.R. \& U.P. Sharma (1995). Community structure of plankton in Kawar lake wetland, Begusarai, Bihar: II Zooplankton. Journal of Freshwater Biology 7: 165-167.

Sharma, B.K. (1995). Limnological studies in a small reservoir in Meghalaya (N.E. India), pp. 187-197. In: Timotius, K.H. \& F. Goltenboth (eds.). Tropical Limnology Vol. II. Satya Wacana University Press, Salatiga, Indonesia.

Sharma, B.K. (2004). Phytoplankton communities of a floodplain lake of the Brahmaputra river basin, Upper Assam. Journal of the Indian Fisheries Association 31: 27-35.

Sharma, B.K. (in press). Phytoplankton communities of Deepor Beel (a Ramsar site), Assam (N.E. India): composition and ecology. In: Barik, S.K. (ed.). Conserving Plants and Ecosystems. NEHU, Shillong.

Sharma, B.K. \& R.M. Lyngdoh (2003). Abundance and ecology of net and phytoplankton of a subtropical reservoir of Meghalaya (N.E. India). Ecology, Environment \& Conservation 9(4): 497-503.

Sharma, B.K. \& C. Lyngskor (2003). Plankton communities of a subtropical reservoir of Meghalaya (N.E. India). Indian Journal of Animal Sciences 73(2): 88-95.

Sharma, S. \& B.K. Sharma (2008). Zooplankton diversity in floodplain lakes of Assam. Records of the Zoological Survey of India, Occasional Paper No. 290: 1-307.

Sinha, A.K., A. Baruah, D.K. Singh \& U.P. Sharma (1994). Biodiversity and pollution status in relation to physico-chemical factors of Kawar lake (Begusarai), North Bihar. Journal of Freshwater Biology 6: 309331.

Sugunan, V.V. (1989). Limnological features in beels: Biotic factors. Bulletin Central Inland Capture Fisheries Research Institute, Barrackpore 63: 128-135

Sugunan, V.V. (1997). Fisheries management of small bodies in seven countries in Africa, Asia and Latin America. FAO Circular No. 933. Rome, 149pp.

Talling, J.F. \& I.B. Talling (1965). The chemical composition of African lake waters. Internationale Revue gesammten Hydrobiologie 50: 421463 .

Vass, K.K. (1989). Beel fisheries resources in West Bengal. Bulletin Central Inland Capture Fisheries Research Institute, Barrackpore 63: 2935.

Yadava, Y.S., R.K. Singh, M. Choudhury \& V. Kolekar (1987). Limnology and productivity in Dighali beel (Assam). Tropical Ecology 28: $137-146$

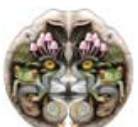

